Annuaire suisse de politique de développement

9 | 1990

Annuaire Suisse - Tiers Monde 1990

\title{
La fuite des capitaux des pays en développement et en Suisse
}

Kapitalflucht aus Entwicklungsländern und die Schweiz

Hans J. Mast

\section{(2) OpenEdition}

\section{Journals}

Édition électronique

URL : http://journals.openedition.org/aspd/1324

DOI : $10.4000 /$ aspd. 1324

ISSN : 1663-9669

Éditeur

Institut de hautes études internationales et du développement

\section{Édition imprimée}

Date de publication : 1 janvier 1990

Pagination : 151-164

ISSN : 1660-5934

\section{Référence électronique}

Hans J. Mast, "La fuite des capitaux des pays en développement et en Suisse », Annuaire suisse de politique de développement [En ligne], 9 | 1990, mis en ligne le 31 mars 2013, consulté le 08 septembre 2020. URL : http://journals.openedition.org/aspd/1324 ; DOI : https://doi.org/10.4000/aspd.1324

Ce document a été généré automatiquement le 8 septembre 2020.

(C) The Graduate Institute / Geneva 


\section{La fuite des capitaux des pays en développement et en Suisse}

Kapitalflucht aus Entwicklungsländern und die Schweiz

Hans J. Mast

\section{NOTE DE L'ÉDITEUR}

Lire l'article original en allemand dans Schweizerisches Jahrbuch für Entwicklungspolitik: « Kapitalflucht aus Entwicklungsländern und die Schweiz », http://sjep.revues.org/ 1150.

\section{AUTEUR}

HANS J. MAST

Senior Economic Advisor, Crédit Suisse - Firt Boston, Zurich 